MUZIKOLOŠKI ZBORNIK - MUSICOLOGICAL ANNUAL X, LJUBLJANA 1974

UDK 784.3 (497.11) Konjović

\title{
SAMOSPEVI PETRA KONJOVIĆA
}

\author{
Zijo Kučukalić (Sarajevo)
}

Petar Konjović je poleg Stevana Hristića in Miloja Milojevića najeminentnejša osebnost generacije srbskih skladateljev, ki se je pojavila na začetku 20 stoletja in je s svojo ustvarjalnostjo zaznamovala konec romantike. Čeprav se je idejno naslanjal na skladatelje predhodne generacije, predvsem na Mokranjca in Marinkovića, ter jemal v skoro vseh svojih delih folkloro kot izhodišče umetniškega ustvarjanja, je glasbeni nacionalizem 19. stoletja razširil in poglobil, tako da mu je dal na podlagi svojih jasno določenih estetskih načel specifičen poznoromantični pečat. Konjović je segel na razna področja glasbenega ustvarjanja, toda njegova najpomembnejša dela pripadajo vokalni glasbi. $\mathrm{Z}$ zanimanjem in ljubeznijo se je loteval uglasbitve pesniških verzov. Zato je razumljivo, da je $s$ posebno afiniteto gojil obliko samospeva s spremljavo klavirja. $\mathrm{Tu}$ je bil njegov neposredni predhodnik Marinković. Konjović je prevzel njegovo romantično tradicijo, vendar je $\mathrm{v}$ svoje samospeve vnesel nove poznoromantične elemente, pri čemer je sprejel modernejša pojmovanja evropske glasbe tistega časa.

$\mathrm{Na}$ začetku 20. stoletja je srbsko meščanstvo, ki je bilo že trdno povezano $\mathrm{z}$ družbenim in ekonomskim razvojem $\mathrm{v}$ Evropi, postopoma začelo prevzemati evropsko kulturno in umetniško tradicijo. Tedaj se je začela pod tem vplivom $v$ Srbiji močno razvijati tudi glasbena tvornost. To pa označuje ne le pojavljanje pomembnih, oblikovanih umetniških individualnosti kot so Konjović, Hristić in Milojević, ampak tudi postavljanje drugačnih kriterijev $\mathrm{v}$ pojmovanju in izražanju estetskih vrednosti. Srbska glasba je tedaj dobila novo kvaliteto $\mathrm{v}$ tehničnem in umetniškem smislu, prišlo je do poglabljanja artizma v kompozicijski tehniki in, kar je zelo važno, do zbliževanja $\mathrm{s}$ sodobnim dogajanjem $\mathrm{v}$ evropski glasbi. Zdaj pritekajo vse močneje moderni elementi, ki so končno pripeljali do stilne spremembe. Ta sprememba pa ni nastopila naglo, konservativna naziranja so se umikala modernim le postopoma in vse je šlo po evolucijski poti, tako da definitivna opustitev preživele romantike ni bila revolucionarnega značaja. 
Kot je že bilo poudarjeno, ni pokazalo pozno obdobje romantike glede na visoko romantiko $\mathrm{v}$ idejnem smislu nikakršnih novih značilnosti. To je bila samo končna faza razvoja tistega stila, ki so ga $\mathrm{v}$ srbski glasbi predstavljala dela Stankovića, Marinkovića ter Mokranjca in čigar ideološka osnova je bil glasbeni nacionalizem. Ta nacionalizem živi tudi naprej $\mathrm{v}$ ustvarjalnosti poznih romantikov, torej prav tako v delih Petra Konjovića. Toda ker je že imel za seboj razvoj $\mathrm{v}$ visoki romantiki in je posedoval njene kompozicijsko tehnične in estetske rezultate, je bilo mogoče graditi nov glasbeni izraz. Heroično obdobje romantike je spadalo tedaj $\mathrm{v}$ preteklost, najmočnejše kreativne sile pa so težile za tem, da se v srbski glasbi ustvari nekaj »novega«, nekaj, kar bo imelo več zveze s splošnim, »evropskim», "svetovnim» kot pa z "našim», »domačim», pod čemer se je razumelo tisto "primitivno in zapoznelo. ${ }^{1}$ Ko so se Konjović, Hristić in Milojević pojavili v srbski glasbi, so gledali nanje mladi sodobniki "kot na mlado falango revolucionarnih pojmovanj in teženj«. ${ }^{2}$

Konjovićevi samospevi so nastajali v letih 1903 do 1925. Skladatelj jih je objavljal od časa do časa, posamezno ali v skupinah. Vsi pomembnejši so bili pozneje zbrani v zbirki, ki nosi naslov »Lirika«. ${ }^{3}$

Prve samospeve "San zaspala" in "Sevdah" je Konjović komponiral na besedila v ljudskem duhu, pri čemer ga je inspirirala melodika bosanske folklore. " "San zaspala ima obliko tridelne pesmi, je svobodno koncipiran in je zgrajen iz treh različnih delov (a b c). Prvi obsega dva pasusa, ki kontrastirata po značaju, čeprav se drugi glede ritmične strukture naślanja na prvega. Drugi del začenja $\mathrm{z}$ obdelavo gradiva klavirskega uvoda, ki je tokrat obogaten $\mathrm{z}$ vokalnim partom, nakar sledi skoro doslovna repriza prvega pasusa iz a dela. To kaže na strukturo prehodnega tipa, ki je med dvo- in tridelno pesmijo, saj se drugi pasus ne pojavi in repriza ni popolna. Tretji del prinaša novo glasbeno gradivo, ki se razlikuje po motivični gradnji, značaju in tempu, pomembna pa je tudi bogata melizmatika $\mathrm{v}$

${ }^{1}$ Konjović P., Miloje Milojević, Beograd 154, 4.

2 Andreis J., Cvetko D., Djurić-Klajn. S., Historijski razvoj muzičke kulture u Jugoslaviji, Beograd 1961, 651. Sam Milojević, eden od predstavnikov te generacije, je imenoval leta 1936, ko je pisal o srbskem glasbenem življenju prvih desetletij 20. stoletja, svoje somišljenike in sebe revolucionarje: »Naši ekspresionisti, in to je generacija revolucionarjev izpred skoro tridesetih let, katerih predstavniki so Petar Konjović, Miloje Milojević in Stevan Hristić... so izrasli iz umetniške estetike; ki je bila močno naslonjena na elemente revolucionarne romantike devetnajstega stoletja, največ iz nove estetike Richarda Straussa ... « Prim. Milojević M., O srpskoj umetničkoj muzici, Srpski književni glasnik XLVIII, 7, Beo$\operatorname{grad} 1948$.

${ }^{3}$ Konjović P., Lirika, 24 pesma za jedan glas i klavir, Beograd 1948. Razen »Lirike« je Konjović napisal še 11 samospevov, tako da jih je skupno 35. Prim. Katalog del članov Društva skladateljev Srbije, 55. Konjović je obdelal za glas in klavir tudi 96 jugoslovanskih ljudskih pesmi, ki so objavljene $\mathrm{v}$ petih zvezkih $\mathrm{z}$ naslovom »Moja zemlja«.

${ }_{4}$ Te pesmi so bile del Konjovićeve scenske glasbe za igro "Zlatija" Osmana Djikića, ki pa ni bila nikoli izvedena. 
glasu, ki poteka nad pretežno homofonim klavirskim partom (prim. 1). Čeprav spominja po svoji ritmični strukturi na folklorni izraz,

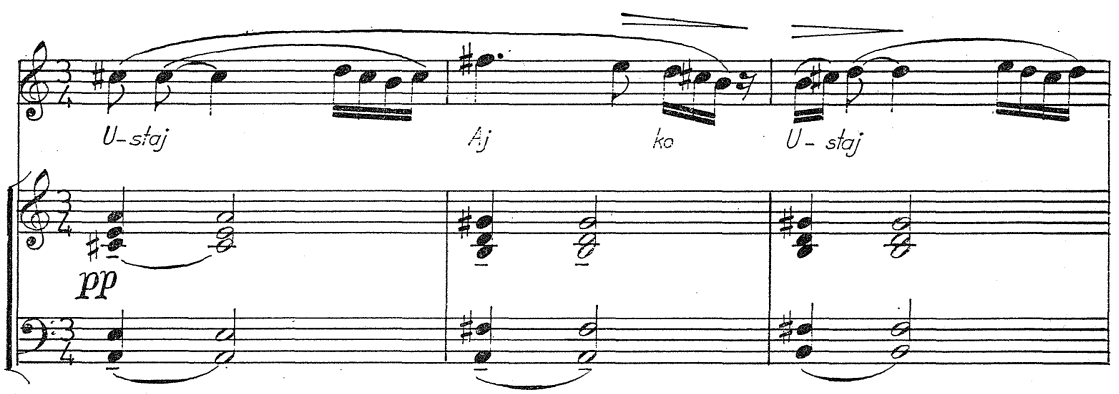

dobi ta melizmatika zaradi značaja harmonske podlage individualen pęčat. Kompozicija se začenja viharno $\mathrm{v}$ fortissimu, s klavirskim uvodom šestih taktov, kjer prinese desna roka $\mathrm{v}$ tekočem gibanju šestnajstink variirano temo prvega dela, medtem ko so $\mathrm{v}$ levi roki karakteristične ritmične figure. Začetna tonaliteta pesmi je C-dur, vendar pripadajo zaključni takti Fis-duru in tako se kaže tipična poznoromantična harmonska gibljivost.

Pesem »Sevdah« je zložena na Djikićeve verze, ki so v ljudskem duhu, ima pa tudi trodelno obliko $\left(\mathrm{a} b \mathrm{a}_{1}\right)$. Pevski part je $\mathrm{v}$ prvem delú enostaven, brez melizmov (prim. 2), b del kontrastira po ritmu

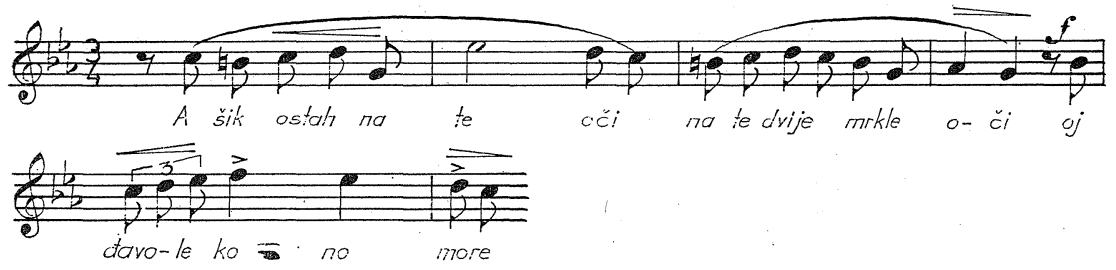

in bogateje ornamentirani melodiki, repriza prinaša varianto melodije prvega dela, katera je obogatena $\mathrm{z}$ melizmatskimi skupinami in različnimi okraski (prim. 3). Odsotnost melizmatike v vokalnem partu

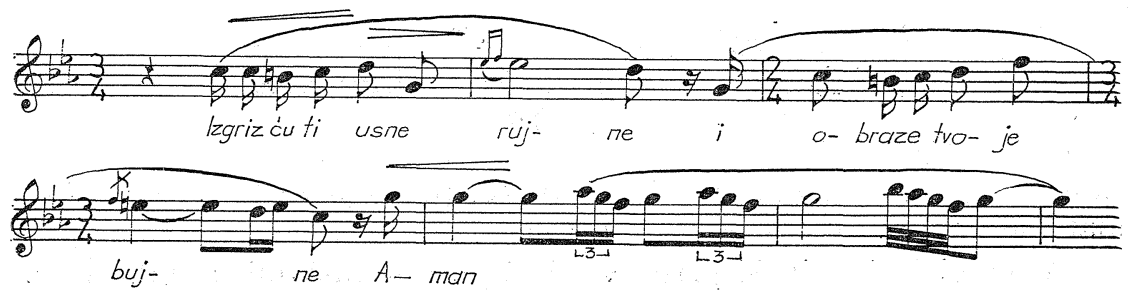

prvega dela dopolnjuje s svojo ornamentacijo klavir, medtem ko je v reprizi obratno; tu je zaradi kolorirane vokalne linije klavirska spremljava brez ornamentacije. Nad codo se v visokem vokalnem 
registru odvijajo zanosni melizmi, ki zaokrožujejo atmosfero celotne kompozicije. Pesem je $\mathrm{v}$ harmonskem pogledu precej enostavna; giblje se v okviru c-mola s pogostim pojavljanjem alterirane četrte stopnje (fis), s čimer je ustvarjena balkanska lestvica. Ta alteracija poudari funkcijo dominantne dominante kot tipičnim pojavom $\mathrm{v}$ harmonizaciji melodije $\mathrm{v}$ folklornem duhu.

Ko je Konjović študiral v Pragi, ga je vpliv evropske glasbe oddaljil od folklornega vira. Tedaj, leta 1905, je nastal tudi samospev »O, pogledaj«, komponiran na besedilo iz "Djulića« Zmaja-Jovana Jovanovića. Ta izraža izrazito lirično razpoloženje, je jedrnat in prekomponiran, bogata in komplicirana ritmična struktura (punktirani ritmi, sinkope, triole, kvintole, različni ritmi med glasom in klavirjem itd.) pa plastično izraža pesniško besedilo. Nekateri melodični elementi, kot naslanjanje na tone razloženega akorda in posebno skok na spodnji vodilni ton $\mathrm{v}$ kadenci, kažejo na oddaljevanje od folklornih vzorov (prim. 4). Čeprav "kompozicija začenja v B-duru,

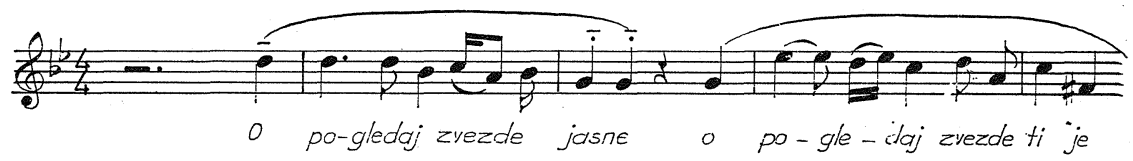

dominira g-mol, ki ni nikjer izrazito poudarjen, sklepni akord pa je njegova dominanta. $\mathrm{S}$ tem je dosežena nedoločenost tonalitete, harmonska nestabilnost, kar je tipična stilna značilnost pozne romantike. V teku celotne kompozicije se intenzivno odvijajo kromatski postopki, pojavljajo se tudi enharmonične zamenjave (prim. 5), zve-

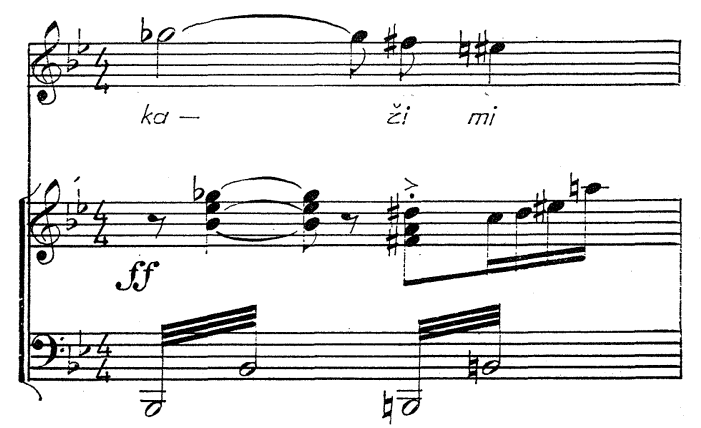

čani kvintakordi in zmanjšani septakordi pa so pogosta sredstva kromatične in enharmonične modulacije.

V Pragi je Konjović prišel v stik tudi s hrvaškimi pesniki, predstavniki tedanje mlade generacije, posebno blizu pa mu je bil Julije Benešić. Verzi njegove poezije, ki je pripadala simbolizmu, so ga navdihnili za uglasbitev pesmi »Ukop « in Iščekivanje». Druga od teh je uspešnejša spričo adekvatnejšega izraza pesniškega besedila in 
splošnega razpoloženja. Samospev "Iščekivanje je prekomponiran z izrazito težnjo, da se združijo vsi elementi za ustvaritev ustreznega vzdušja. Melodika glasu izhaja neposredno iz deklamacije teksta, kot zvočna plastika govora, in za njeno ritmično strukturo je posebno značilno gibanje $\mathrm{v}$ triolah. Harmonija ima predvsem koloristični značaj, s senčenjem krepi moč pesniške besede in daje klavirskemu partu individualne poteze, ki so poudarjene tudi s kontrastirajočo ritmično strukturo (prim. 6). Tako je Konjović tu po-
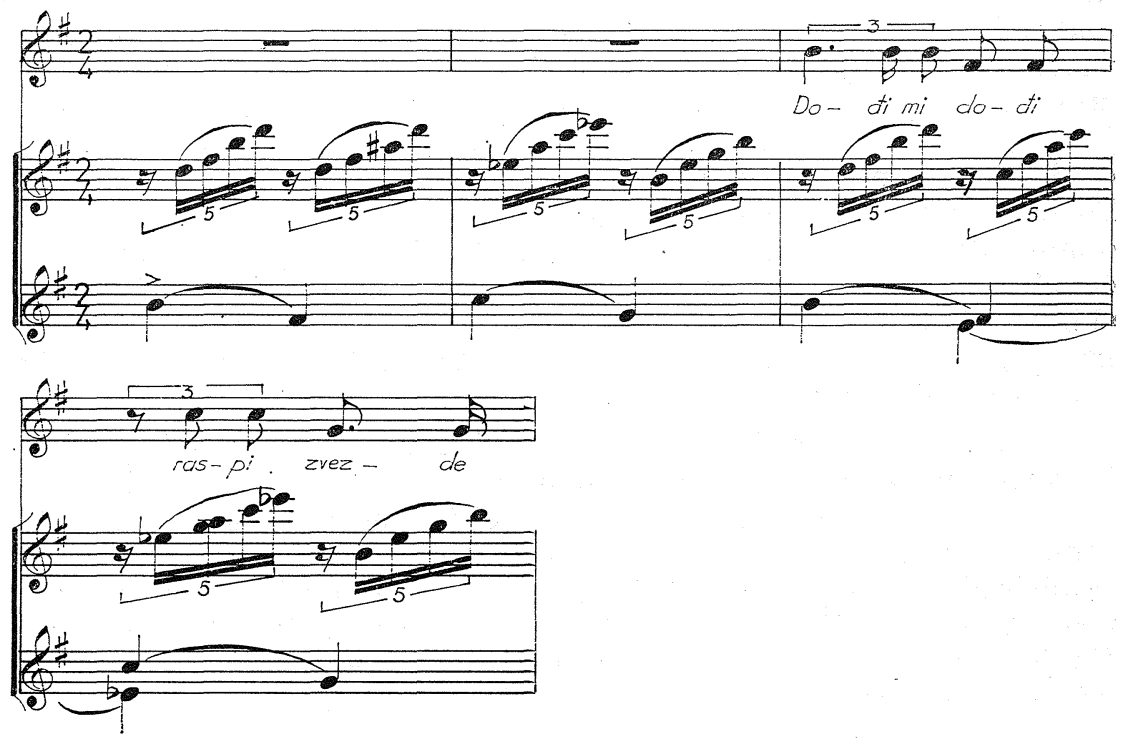

kazal, da je osvojil pridobitve moderne evropske glasbe tistega časa, $\mathrm{v}$ čemer se je približal predvsem impresionizmu.

Ta njegova razvojna pot je posebno značilna za samospev »Noč" in "Chanson", ki ju je komponiral na verze Mihovila Nikolića leta 1906, v času, ko verjetno sploh še ni poznal Debussyjevih del. ${ }^{5}$ Nekateri tehnični in izrazni elementi, ki jih je Konjović uporabljal pri skladanju teh samospevov, tako npr. raztrganost fraze na posameznih mestih, dodajanje sekund, za katere je značilno, da ne težijo za razširitvijo, svobodna uporaba akordov tujih tonalitet, posebno pa izrazito koloristično tretiranje harmonije, kažejo določeno oddaljevanje od poznoromantičnih stilnih karakterističnosti.

Vendar Konjović ni bil dolgo $\mathrm{v}$ vodah glasbenega kozmopolitizma; že leta 1906 je namreč izšla njegova zbirka petih samospevov za glas in klavir $\mathrm{z}$ naslovom »Iz naših krajeva«. Nastala je kot rezultat Konjovićevega naziranja, da »daje nacionalna glasba ustvarjalcu neslutene možnosti in da ima vsak narod pravico do svoje

5 Prim. Mosusova N., "Lirika Petra Konjovića, Zvuk, 1967, 75-76, str. 4-5. 
nacionalne glasbe, medtem ko so skladatelji dolžni, da jo ustvarijo « ${ }^{6}$ Prva pesem iz te zbirke - pozneje je bila uvrščena $\mathrm{v}$ »Liriko« - je "Pod pendžeri« in zanjo je napisal Konjović tudi besedilo. Kompozicija je postala popularna in je tako zelo prodrla $\mathrm{v}$ ljudstvo, da jo imajo, podobno kot Jenkovo "Gde si dušo, gde si rano«, za narodno pesem. ${ }^{7}$ Po obliki je pesem z refrenom, ki se ponavlja, kaže pa nekatere tipične značilnosti poznoromantičnega nacionalizma. Grajena je iz preprostega motivičnega gradiva, ki ga karakterizira bogato melizmatsko okraševanje. Refren kontrastira po tonaliteti - nasproti f-molu iz prvega dela se javlja istoimenski dur —, živahnejšem značaju in hitrejšem tempu. Motivi iz instrumentalnega uvoda služijo tematično v prvem delu, vendar so akcenti spremenjeni in pojavlja se ornamentacija. Coda je iz istega gradiva kot uvod, samo da je - z namenom pomiritve ob koncu - razširjena za dva takta. Pogosto spreminjanje metrike, zastoji (korone) - navadno na subdominanti - in rubato dajejo tej skladbi izrazito sevdalinski značaj. Harmonska struktura temelji na načelu kontrastiranja istoimenskih tonalitet različne vrste, kroženje po kvintnem krogu $\mathrm{v}$ refrenu pa lahko razložimo kot uporabo izventonalnih dominant $\mathrm{v}$ okviru razširjene glavne tonalnosti.

Tudi ko se je vrnil s študija v Pragi (1907), je Konjović še naprej komponiral samospeve $\mathrm{z}$ nacionalnim značajem. Med njimi se odlikuje "Devojče, vraže», ki je tudi bil objavljen v zbirki "Lirika». Ta samospev razodeva duh in značaj vesele in preproste ljudske pesmi, inspirirali pa so ga verzi Milorada Petrovića iz njegovega popularnega ciklusa "Seljančice.$^{8} \mathrm{Z}$ glasbenim oblikovanjem teh verzov je Konjović pesniško razširil okvir tematike, pokazal je sposobnost, da prepričljivo izrazi veder značaj folklornega duha.

Jugoslovanska glasbena kritika je že tedaj izkazala pozornost Konjovićevim samospevom in tako so se ob izidu njegove tiskane zbirke "Pesme za jedan glas i klavir«, ki je vsebovala šest pesmi (»O pogledaj«, »Chanson«, »Noć«, »Reci meni beli krine«, »Večernja pesma« in "Prisen«), pojavili dve recenziji. Antun Dobronić se je izrazil zelo pohvalno o značilnostih teh skladb in o Konjovićevem ustvarjalnem izrazu ter poudaril, da je njegova glasba predvsem. plastična, da zanj petje ni nič drugega kot emfatični govor. Vendar je rekel, da je streba večkrat grajati preveliko drznost v modulaci-

${ }^{6}$ Gl. Mosusova N., ib., 5.

7 Ta Konjovićeva pesem je uvrščena tudi v zbirko južnoslovanskih narodnih pesmi Heinricha Möllerja (1875-1958), ki je v letih 1923-1929 izdal štirinajst zvezkov pesmi raznih narodov.

80 teh verzih je zapisal sam Konjović tole: "Lahko bi rekli, da so se naši skladatelji kosali, kdo bo pogodil in vnesel več svežosti, duhovitosti, neke gracioznosti, primitivne koketerije in dovtipnosti $v$ te kratke, metrično precizne, jasne in ljubke verze primitivnega, vendar nadarjenega pesnika, šumadinca, ki je uspel v času med Vojislavom Ilićem na eni in Dušićem na drugi strani uvesti preprost ljudski žargon - tako kot ga je bil nekoliko prej v pripovedništvu Janko Veselinović - in inspirirati prve originalne zvoke, ki so nam jih že naznanili Mokranjčevi rukoveti, 
cijah in tu in tam harmonsko prenatrpanost, ki je nastala zaradi nepotrebnega podvajanja partov«. Razen tega misli avtor te recenzije, da je včasih Konjovićeva klavirska spremljava bolj zanimiva »kot sam spev« in sklepa, da Konjović realizira dobro pojmovano Wagnerjevo in Debussujevo estetiko zelo samokritično. ${ }^{9}$ Emil Sachs, avtor druge recenzije, ima sicer dosti pripomb na račun izraza in harmonije, vendar na koncu ugotavlja da »imajo te pesmi za srbsko glasbeno literaturo velik pomen, ker $\mathrm{v}$ njih srbska glasba ubira moderno pot.« ${ }^{10}$

Prav leta 1910 je Konjović komponiral na ljudsko besedilo tudi "Nane, kaži tajku«, vendar tedaj verjetno ni poznal njene ljudske melodije, katero je obdelal šele pozneje v zbirki »Moja zemlja«. ${ }^{11} \mathrm{~V}$ tej pesmi je skladatelj, ki je izhajal iz ljudskega vira, oblikoval melodiko širokih linij s prizvokom sevdalinke in z zelo diskretnimi orientalskimi elementi, vendar je s svojo kompozicijsko tehnično obdelavo umetniško razširil in oplemenitil izrazno kvaliteto ljudskega duha. Samospev "Nane, kaži tajku« - po obliki je prekomponiran z reminiscenco na koncu - spada po bogastvu in raznolikosti motivične izpeljave med najbolj zanimive Konjovićeve kompozicije. Kot ideja za celotno muzikalno gradnjo je motivična izpeljava zajeta $\mathrm{z}$ več strani, in to vešče in strokovnjaško. Nekoliko motivičnih obrazcev, ki so zlasti ritmično izraziti, je razpredeno skozi celo kompozicijo in iz njih izhaja tudi njena glasbena obdelava. Konjović je tu uporabil skoro vse postopke motivičnega dela: melodične in ritmične spremembe, razširitev in skrajšanje, relativno $v$ večji in absolutno $v$ manjši meri, in še drugo. $\mathrm{Za}$ ritmično strukturo je posebno značilen punktiran ritem, ki se pojavlja $\mathrm{v}$ več variantah in se prenaša na različne dobe takta, s čimer je dosežena raznolikost in omogočena sprememba harmonske napetosti (prim. 7). Ta ritmična

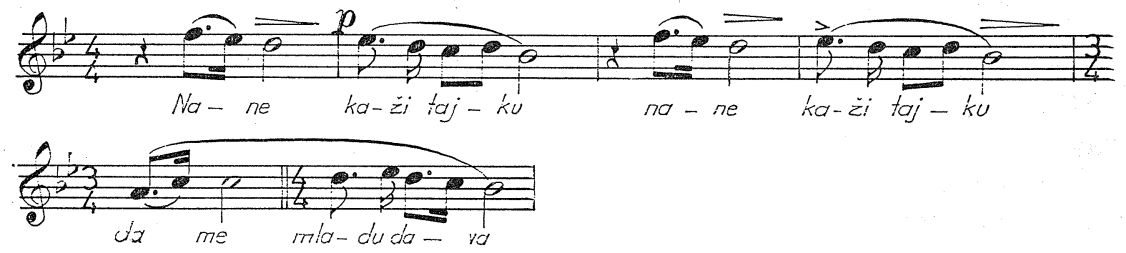

izpeljava je $\mathrm{v}$ tesni zvezi' $\mathrm{z}$ metriko teksta, rezultat je popolnoma pravilna deklamacija besede. Svetla barva B-dura, harmonski kolorit, ki dominira $v$ tej pesmi, je nekajkrat zamenjana $z$ barvitostjo molove paralele, ta kontrast pa samo podčrtuje koloristični efekt.

Leta 1916 je Konjović napisal samospev »Sabah" in ga namenil zagrebški pevki Mariji Strozzi, ki je bila odtlej pogost in zelo uspe-

${ }^{9}$ Dobronić A., Božinski P. K., "Pjesme za jedno grlo i glasovir", Savremenik 5/1910, 9, str. 674-675.

10 Sachs E., Pesme P.K. Božinskoga, Letopis Matice srpske, 1910, zv. 268, str. $70-80$.

${ }_{11}$ Mosusova N., ib., 7. 
šen interpret njegovih pesmi. Ta kompozicija ima tridelno obliko ( $a$ b $a_{1}$ ), ki jo diktira izvenmuzikalna vsebina: med zanosno mujezinovo molitev $\mathrm{z}$ minareta je uveden motiv dekliške ljubezenske tožbe. Za instrumentalnim uvodom, v katerem se vrstijo razloženi akordi tonike, dominantne dominante in dominante, sledi tonična harmonija (b-mol), nad katero začne lebdeti široka in bogato, orientalno kolorirana melodija. V prvem delu se melizmi vokalnega parta izmenjujejo z razloženimi akordi klavirske spremljave, tako da je doseženo stalno gibanje. Srednji del je daljši in bolj kompliciran, po značaju živahnejši, motivi in submotivi pevskega parta so izpeljani tudi v klavirju, zaradi česar prihaja na posameznih mestih do dialoga med glasom in instrumentom. Repriza je strnjena, skrajšan je uvodni del, tudi faktura klavirske spremljave je spremenjena $\mathrm{V}$ smislu večje razgibanosti. V zvezi s harmonsko strukturo je treba opozoriti na tonični akord, ki nastopa brez terce, a je obarvan s sekundo in kvarto, torej $\mathrm{s}$ toni drugih funkcij, kar tudi kaže na poznoromantični izraz (prim. 8).

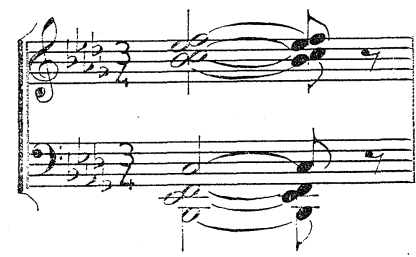

Tudi Konjović ni ostal ravnodušen do poezije Vojislava Ilića. Sam je ugotovil da je "pri nas komaj še skladatelj z lirično naravo, ki ga niso zamikale Vojislavove strofe«. ${ }^{12}$ Tako je bil Konjović inspiriran po njegovi poeziji v samospevu »Čekanje«, kjer ji je dal glasbeni komentar, ki je povezan s psihološkim ozadjem besedila. Ta pesem ima tridelno obliko ( $\mathrm{b} \mathrm{a}_{1}$ ), ki je $\mathrm{v}$ zvezi $\mathrm{s}$ tekstom znatno razširjena. Prvi del je velika perioda, srednji predstavlja vrsto stavkov, $\mathrm{v}$ reprizi pa se doslovno ponavlja samo prvi mali stavek velike periode, drugi je variiran, zlasti $\mathrm{v}$ harmonskem pogledu in klavirski spremljavi, dočim melodično spominja na četrti stavek velike periode iz a dela. Na koncu nastopi melodika, ki je vezana na gradivo prvega dela, $v$ klavirski spremljavi pa pride do reminiscence na srednji del. Zelo jasen primer enharmonične modulacije je na prehodu iz prvega $\mathrm{v}$ drugi del, kjer je tonični akord as-c-es enharmonično preimenovan $\mathrm{v}$ gis-his-dis in tolmačen kot dominanta nastopajočega cis-mola (prim. 9). Isti postopek, samo v obratni smeri, je ponovljen tudi pri prehodu iz srednjega dela $\mathrm{v}$ reprizo. $\mathrm{Za} \mathrm{b}$ del je značilna melodija, ki se vzpenja skokovito, a se spušča mirnejše, pri čemer se naslanja na tone, ki v določenih akordih izražajo neko napetost.

12 Konjović P., Miloje Milojević, 89. 


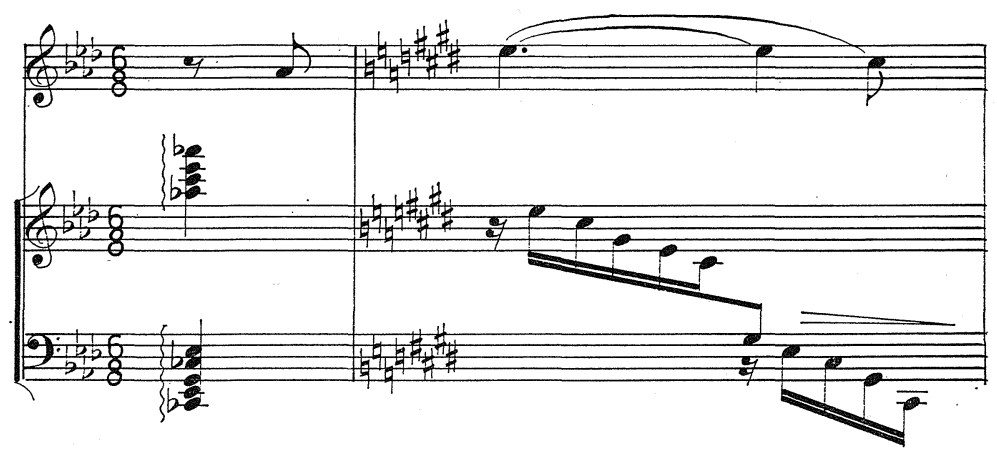

Znane verze Milorada Mitrovića »Bila jednom ruža jedna«, ki so inspirirali še druge srbske skladatelje, je komponiral tudi Konjović. Ta samospev je imenoval "Balada", nastal je leta 1917 in spada med njegove zadnje samospeve lastne invencije. Ima tridelno obliko, v kateri se za vsakim delom pojavi refren, ki je vedno nekoliko spremenjen ( $a r b r_{1} a_{1} r_{2}$ ). Prvi del ima baladno pripovedni značaj, drugi vsebuje določene dramatske akcente, tretji pa prinaša razplet v smislu delne reprize (samo glede ritma). Ko se pojavi refren prvič, je bogato ornamentiran le $\mathrm{v}$ vokalnem partu, pri njegovem tretjem nastopu na koncu skladbe pa je tudi klavirska spremljava izpopolnjena s figuracijami. Drugi nastop refrena izza srednjega dela je tudi melodično variiran: sodi takti so identični, lihi pa spremenjeni v smislu močnejšega podčrtavanja bolestne ekspresije zaradi razpleta dejanja (namesto intervala velike terce nastopi zvečana kvarta, prim. $10 \mathrm{a}$ in b). Prvi del je v h-molu, drugi v fis-molu, trejti, čigar besedilo

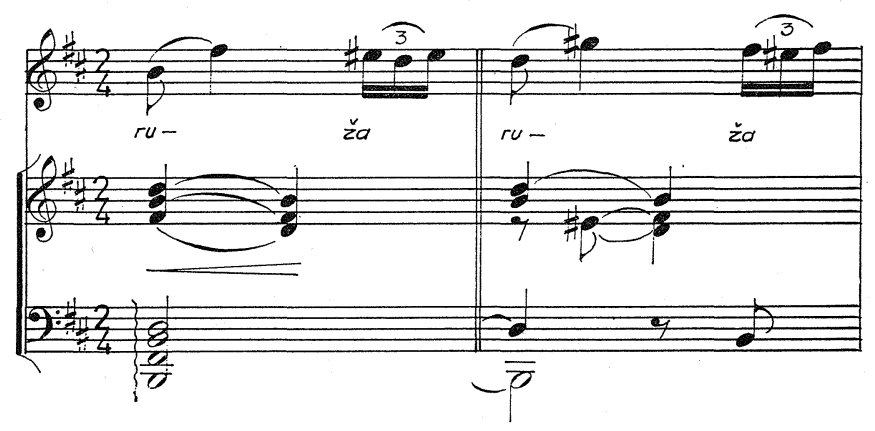

zahteva svečan ton, pa $\mathrm{v}$ paraleli osnovnega tonskega načina, $\mathrm{v} \mathrm{D}$ duru. V tej skladbi pride do izraza še ena poznoromantična značilnost Konjovićevega stila. Da bi dosegel večjo melodično ekspresivnost in harmonsko napetost, je avtor samospeva tolmačil alterirane tone, prehodne in menjalne, kot vodilne tone glede na naslednji ton. Takšne alternacije je celo podvajal in tako dosegel še močnejše izrazne učinke. 
Konjovićeva ustvarjalnost na področju samospeva predstavlja vrh razvoja poznoromantičnega »lieda« v Srbiji. Konjović je le za kratek čas opustil nacionalizem, najizrazitejšo značilnost srbskega romantičnega samospeva nasploh, in se oklenil splošnega stila evropske glasbe tistega časa. Hitro se je vrnil $\mathrm{k}$ svojemu prvotnemu naziranju, tako da je bilo vse njegovo nadaljnje delo na področju samospeva usmerjeno $\mathrm{v}$ nacionalni izraz. Vsekakor največja Konjovićeva zasluga je $\mathrm{v}$ tem, da mu je uspelo spojiti formalno-tehnične dosežke evropske pozne romantike s specifičnimi značilnostmi ljudske glasbene tradicije in tako vtisniti svojim samospevom lasten pečat. Konjović je izhajal iz teksta, ki ga je imel za integralni del vsake vokalno-instrumentalne skladbe. »Mnogi umetniški samospevi s klavirjem bodo napravili pozitiven umetniški vtis še zlasti, če preberemo ali recitiramo njihovo besedilo, seveda $s$ pogojem, da je ta zares pesniški. Pogosto naredi klavirski part, ,spremljava', ako jo odigra dober mojster, pravi efekt takoimenovane absolutne, čiste, ,prave glasbe. Vendar spoj, simbioza enega in drugega elementa, zajamči $\mathrm{v}$ vokalno instrumentalni glasbi, še posebno $\mathrm{v}$ samospevu s klavirjem, nov, drugačen umetniški vtis «. ${ }^{13}$ Tako je bila muzikalna obdelava besedila za Konjovića poglavitno vprašanje, ker je le z uspešno realizacijo zvočne plastike péte besede možno izraziti duha in značaj pesniških verzov. Konjović je v svojih samospevih zahteval ravnotežje besede in melodije, $v$ tem oziru pa je imel jasno opredeljeno stališče, ki ga je uporno zastopal in izvajal. V poeziji je iskal in našel inspiracijo za melodično oblikovanje, iz katerega je potem izhajala klavirska spremljava kot instrumentalni tolmač značilnosti besedila. »Iz vira čisto vokalne, péte, a včasih skoro govorne recitativne melodije besedila nastane v drugi fazi v vokalno-instrumentalni obliki simbioza, medtem ko se $\mathrm{v}$ tretji in poslednji pogosto sublimira substanca $\mathrm{v}$ čisti tonski, instrumentalno zvočni manifestaciji« ${ }^{14}$

$\mathrm{V}$ izraznem in kompozicijsko tehničnem smislu kažejo Konjovićevi samospevi vse lastnosti pozne romantike. Ta se manifestira v uporabi skoro izključno prekomponirane oblike in njeni koherentni gradnji, v ekspresivni in kromatično bogati melodiki, $\mathrm{v}$ ritmični strukturi, ki vselej adekvatno izraža metrične značilnosti teksta, v harmoniji, ki je kot dejavnik glasbene izraznosti postala enakopravna melodiji, in končno $\mathrm{v}$ popolni individualizaciji klavirskega parta. Vendar pa najbolj markantno izraža stilno fiziognomijo teh Konjovićevih kompozicij njihov harmonski jezik, obogaten $\mathrm{z}$ novimi kvalitetami, ki krepijo moč učinkovanja poetične besede. Njegova osnovna značilnost je kromatika in njen intenzivni tok, iz katerega nastaja globok umetniški vtis. Oddaljevanje od tonalnega centra in slabitev funkcionalne povezanosti akorda $\mathrm{v}$ tonaliteti, bogata uporaba izventonalnih harmonij (dominantnih in subdominantnih), kromatične in enharmonične modulacije in podobno. vse to izpričuje

${ }^{13}$ Konjović P., Miloje Milojević, 90.

14 Mosusova N., ib., 2. 
tipične poznoromantične značilnosti harmonske strukture Konjovićevih samospevov.

Glede na to so vse pridobitve poznoromantičnega stila samospeva v Srbiji najjasneje izražene v Konjovićevih kompozicijah. Konjović je asimiliral elemente evropske glasbe tistega časa, med drugim Wagnerjevo kromatiko in ekspresivnost in Janáčkov recitativno deklamatorični stil ter jim dal individualno, nacionalno obarvan ustvarjalni izraz. Konjovićev nacionalizem ne izhaja iz citatov ljudskih pesmi. Svojo glasbeno intonacijo bazira ta skladatelj na načinu mišljenja in kreiranja kot obstaja med ljudstvom, pri čemer sprejema psihološke karakteristike folklore kot osnovo za svoj glasbeni izraz. Nadaljnji postopki nosijo značaj njegove umetniške osebnosti.

Ko primerjamo Konjovićevo ustvarjalnost na področju »lieda" s samospevi njegovih srbskih sodobnikov, predvsem s Hrističevimi in Milojevićevimi, moramo poudariti, da je Konjović glede na Hristića pokazal več strasti in patetičnosti v izrazu, razvitejši smisel za ustvarjanje napetosti in gradacij in mnogo močnejši dramski talent. To je dosegel $\mathrm{z}$ uporabo bogatejših izraznih sredstev, pa tudi njegov temperament je bil bolj ekspanziven in manj zadržan kot Hristićev. V primerjavi z Milojevićem je bil Konjović močneje povezan z romantičnim nacionalizmom in potemtakem $\mathrm{v}$ idejnem smislu bližji tradiciji. Medtem ko se je Milojević v glavnem naslanjal na kozmopolitski duh evropske glasbe tistega časa in pri tem bogatil svojo psihično in ustvarjalno osnovo s pridobitvami modernejših naziranj, srečujemo pri Konjoviću redko elemente opuščanja poznoromantičnega nacionalnega stila; Milojevićeva glasba je izražala sodobnejše stilne karakteristike.

Pa tudi glede na ustvarjalnost drugih južnoslovanskih narodov na tem področju se je Konjović odlikoval kot izjemna osebnost. Bil je pred svojimi sodobniki na Hrvaškem, pred Josipom Hatzejem in Vjekoslavom Rosenbergom-Ružićem tudi kar se tiče umetniške ravni in izrazne moči svojih kompozicij, v določenem smislu pa je bil tudi pred Blagojem Berso. Konjović se je namreč v svojem času postavil dosti bolj določeno kot Bersa. Uspelo mu je spojiti formalno tehnične dosežke evropske pozne romantike s specifičnimi karakteristikami ljudske glasbene tradicije in dati svojim samospevom lasten izraz. Odnos do ljudske pesmi mu je omogočil, da se je v določenem zgodovinskem trenutku izognil eklekticizmu, nad katerega se Bersa ni vselej mogel povzpeti. Na Slovenskem je v tem času najeminentnejša osebnost na področju samospeva Anton Lajovic. S svojo izrazito lirsko čustvenostjo, pri čemer je asimiliral duha slovenske ljudske pesmi, se je Lajovic vključeval s svojimi samospevi v evropski okvir ne le formalno tehnično in stilno, ampak je v njih izrazil tudi specifičnost nacionalnega duha in senzibilnost. V tem smislu je bil Konjović blizu Lajovicu. Vsak od njiju je z doseženo visoko kompozicijsko tehnično in umetniško estetsko ravnijo $\mathrm{v}$ določenem družbenem in nacionalnem okviru povezoval obliko samospeva $\mathrm{z}$ dosežki evropske ustvarjalnosti na tem področju. 
Po vsem, kar je bilo rečeno, smemo sklepati, da je Konjovićevo delo na področju samospeva $\mathrm{v}$ srbski glasbi zaznamovalo konec zapoznelosti srbske glasbene ustvarjalnosti $\mathrm{v}$ primerjavi $\mathrm{z}$ evropsko. $\mathrm{S}$ tem, da je pisal glasbene oblike, ki so nosile značilnosti visokega profesionalnega artizma in jasne idejno estetske in stilne opredeljenosti, je Konjović naznanil začetek nove razvojne dobe.

\section{SUMMARY}

Petar Konjović represents one of the outstanding personalities among those Serbian composers who were at the beginning of the 20th century announcing the end of romanticism in Serbia. In accordance with his aesthetic principles he raised Serbian 19th century musical nationalism to a higher level enriching it with specific late romantic traits.

Konjović"s lieder were composed between 1903 and 1925. From time to time he published them, separately or in groups, but the most important ones were issued later, in a collection entitled "Lyrics". This collection comprises twenty-four compositions which represent the summit of the late romantic lied in Serbia. Only for a short period did Konjović abandon nationalism, the most characteristic feature of the Serbian romantic lied, and paid tribute to the international style of contemporary European music. Soon he returned to his former views, so that his whole subsequent compositional activity in the field of the lied was nationally oriented. However, it should be emphasized that he succeded in amalgamating technical developments of late European romanticism with the characteristics of the vernacular musical tradition.

He proceeded from the text, considering it an integral part of every vocal-instrumental composition. A musical treatment of the text was for Konjović of basic importance, for only an adequate plasticity of sound of the words sung could adequately express the spirit and characteristics of the poetic verse. He insisted upon an equilibrium between the text and the melodic line. In poetry he sought and found inspiration for his melodical designs from which the piano accompaniment resulted, as an instrumental interpreter of the textual characteristics.

As regards expression and compositional technique Konjović's lieder show all the traits of late romanticism. These are reflected in the nearly exclusive application of the through-composed form and its coherent structure, in expressive and chromaticly rich melodics, in the rhythmical structure, always in keeping with the metrical subtleties of the text, in harmony which has become of equal expressive importance as the melody, and last but not least, in the complete individualization of the piano part. Nevertheless, it is Konjović's harmonic language that most powerfully "carries" the effect of the poetic text and most imposingly characterizes the stylistic physiognomy of his compositions. Digressions from the tonal centre, weakened harmonic functions within a given tonality, rich use of "external" (dominant and subdominant) harmonies, chromatic and enharmonic modulations etc. are typical late romantic traits of the harmonic structure of Konjović's lieder. 